\title{
Visit Transylvania! Transylvania Representations of Tourists Coming from Abroad
}

\author{
Gyöngyi Pásztor \\ UBB Cluj \\ Anita Dózsa \\ UBB Cluj
}

\begin{abstract}
The subject of the present study is Transylvania ${ }^{1}$ as a tourist destination, more precisely the analysis of what Transylvania means for the foreign tourists visiting here, and what meaning they attach to it. The timeliness of the issue is given by two factors. On the one hand the number of events with a touristic appeal has grown in the past years in Transylvania, and similarly the number of tourists has risen. On the other hand, writings that recommend Transylvania as an outstanding destination are more and more frequent in the international public sphere, in other words, it increasingly appears on the map of international tourism.
\end{abstract}

Keywords: Transylvania, Representations, Tourists, Abroad

\section{Introduction}

A most defining moment of this trend occurred in 2016, when Lonely Planet placed Transylvania on the top of the lists of the most recommended regions. According to Lonely Planet the most important characteristics of Transylvania are its romantic and untouched landscapes and mountains, as well as its historical castles, churches and their specific architectural styles. In our research we tried to find out what tourists visiting Transylvania talk about with respect to this region, and in what way do they formulate their views. We consider that the significance of the present study consists of the fact that it analyses the demand side of tourism, the standpoints and observations of those visiting here, as opposed to earlier similar researches which had presented touristic offers and related contents.

The unit of analysis are entries (comments, recommendations) on various tourist sites written by non-Romanians and nonHungarians who visited Transylvania. The research method is content analysis, especially the semantic network analysis and discourse analysis, since these methods are usefull not only in understanding of narratives but can be used to identify topics within the narratives.

As result it can be said that the representations produced by the tourists show a complex image of Transylvania: urban in one respect, with significant historical traditions, and yet at the same time close to nature, simultaneously offering the chance for active relaxation and tranquil astonishment. Its authenticity primarily appears in connection with the countryside, the way of living, the gastronomy, and the culture of its inhabitants. By the commodification of the places of interest, the post-modern interpretation of the thematic activities, fairs, events, parks, squares Transylvania has become a colourful, globally marketable place.

\footnotetext{
1 Transylvania here means the two Western and the Central development regions of Romania (North-West, West and Centre), covering the territories of the historical regions of Transylvania, the Partium, the Banat and Maramureș.
} 


\section{Tourism in Transylvania}

In spite of the fact that Romania possesses quite a number of endowments that tourists can find attractive, its tourism is weak in an international context (Talpas \& Pál, 2011). According to the data of Eurostat 2015 the tourist traffic of Eastern European states is increasing with the largest intensity among EU member states, Romania being the country with the highest growth rate.

According to the data of the Romanian National Institute of Statistics, the number of tourists in 2016 exceeded 11 million, which means an 11 percent growth as compared to 2015 and 30 percent in comparison with 2014. In a regional breakdown the tourist traffic and the growth rate of tourism in the Transylvanian regions are higher than the country average. 44 percent of the tourist arrivals to Romania are oriented to Transylvania, 24 percent to Moldova, 19 percent to the Capital and its vicinity and 14 percent to Oltenia and Muntenia.

Figure 1. Tourist traffic in the regions of Romania between 2000-2016 (thousand persons)

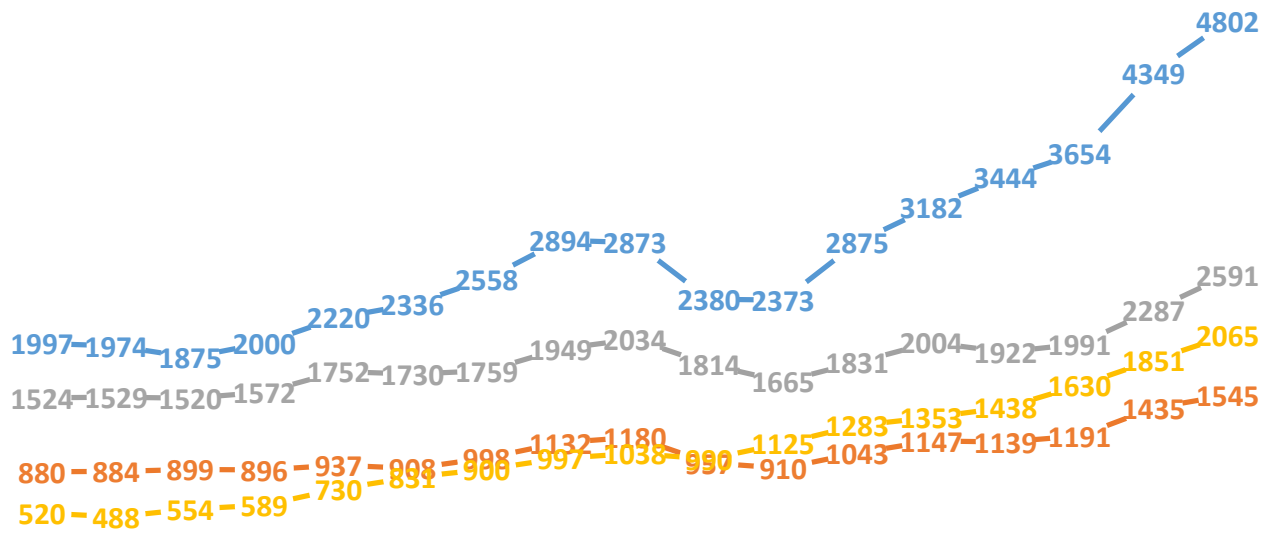

20002001200220032004200520062007200820092010201120122013201420152016

$$
\text { - - Transylvania }- \text {-Oltenia, Muntenia }- \text {-Moldova, Dobrogea }-=\text { Bucharest, llfov }
$$

Almost 19 percent of the tourists visiting Transylvania in 2016 (903 thousand people) arrived from abroad, a 13 percent growth compared to 2015 and 34 percent compared to 2014. Broken down according to their countries or regions of origin most tourists came from the European Union (54\%), followed by other European countries like Moldova, Ukraine, Turkey (39\%), Asia (4\%) and North America (3\%).

\section{Research Methods}

In order to answer the question, we used contents analysis, and within it semantic network analysis and discourse analysis as research methods (see Péter, 2014), as in addition to the understanding of narratives, these methods are suitable in the identification of the various topoi within the narrative. The aim of the contents analysis is the interpretation of the analysed texts and the reproduction of their latent contents, thus our objective when using the method is to provide a structure for 
the totality of the information appearing in the text (Popping, 2000). As all discourses organise meaning around points of junction, the text gains a meaning by the connections between these junctions (Jorgensen \& Phillip, 2002). As a result of network analysis the connections within the text became apparent. With the help of the semantic network the strength of these connections could be detected, as well as the positions of the keywords within the network, and the directions of the elements towards each other. The central theme was showcased, together with the key notions that ensure the links between the clusters. From the composition of the network we could deduce how and in what text surroundings certain themes, given keywords/notions appear and what kind of groups and topoi take shape along the text (Péter, 2014). The advantage of the applied method is that with its help the quantity of analysed text can be increased, while the same time the topoi produced can be confirmed by quantitative data, thus the meanings within the connections can be better interpreted by the application of qualitative methods.

Analysed units in this case are posts, comments, recommendations on various touristic portals. Data collection was conducted on three levels: in the first step the selection of web pages was carried out, which was followed by the collection of comments and selection according to the languages they have been made. The last step consisted of the gathering of available data referring to the persons who made the selected comments such as gender, country of origin, perhaps age and the way of travelling. Exclusively those comments were taken into consideration, which had been written by foreign tourists in English, as these were relevant for the purposes of our research. Thus the final text field contained 843 posts, from eight different webpages. ${ }^{1}$

Subsequently, a data base suitable for the content network analysis of the network was prepared, in which the keywords that reproduce the contents of the text mark the nodes that are connected to the keywords within a post. The number of keywords developed like this, serving as the basis for the analysis is 227 , whereas the number of connections among them is 4,742 .

Using the Gephi network analysis programme, the created network of notions was analysed with the help of the following indicators: average degree, which showed the average number of connections to a node, modularity, by the help of which we could find out how many thematic groups (communities) were formed within the text network, network diameter, which showed how many steps had to be made in order to reach from a node at one part of the network to a node in another part (Hanneman \& Riddle, 2005). The visual representation of the network was created with the Force Atlas procedure. In what follows, we will present the more detailed description of the indicators that are more significant from the perspective of network analysis, the formed networks, as well as the analysis of the created main themes and groups.

\section{The Structure of the Text Network}

Some important indicators from the perspective of network analysis have already been mentioned earlier. In what comes, more details will be given about these, showing how they shape the networks, why they are important for the formation of topoi, and which are the places where these main groups appear. The table below presents the most important indicators of the network.

\footnotetext{
1 These webpages were the following ones:

http://www.transylvania-discovery-tours.ro/en/Travel/testimonials/ (15.04.2016.)

http://www.romania-tours.ro/testimonials.php (15.04.2016.)

http://www.yourguideintransylvania.com/reviews/ (15.04.2016.)

http://dractours.com/testimonials.htm (15.04.2016.)

http://bucharestcitytour.com/feedback (15.04.2016.)

http://www.viatransylvania.com/transylvania-travelers-reviews.html (15.04.2016.)

http://secrettransylvania.co.uk/index.php/feedback/ (15.04.2016.)

https://www.tripadvisor.com/Attractions-g317135-Activities-Transylvania.html

(20.04.2016.)
} 
Table 1: Main indicators of network analysis

\begin{tabular}{|l|l|}
\hline Indicators & Values \\
\hline Nodes & 227 \\
\hline Edges & 4742 \\
\hline Graph Density & 0.185 \\
\hline Average Path Length & 1.851 \\
\hline Network Diameter & 3 \\
\hline Average Degree & 41.78 \\
\hline Modularity & 0.184 \\
\hline
\end{tabular}

Source: Based on our own calculations

Based on the indicators in the above table one can say that the keywords form a compact text network, where the distance between two random nodes is 3 , i.e. an average number of three steps must be made in order to reach from one end of the network to the other. The low modularity of the network shows that the most important keywords, which form a thematic cluster, at the same time also create a connection with thematic groups. The average degree of the network shows the average number of connections of a node. In this case, the node with the highest number connections has 147 connections, while the lowest such value is 7 .

Keywords obviously do not have the same weight in shaping the text network, as more frequently a keyword is mentioned, respectively the more connections it has got, the more central position it takes in the network. Figure 2 represents the network in function of the centricity of its nodes, i.e. it shows how many edges a node has got. Key notions with more connections are shown larger. These are the notions, which have got an outstanding significance in the text field, as they shape its contents. Words with most connections are 'historical', appearing with 147 connections, followed by 'Brașov' with 127 connections, then 'view' with 124, 'old' with 122, 'town' with 117, and 'restaurant' with 111 . This is shown on the next figure.

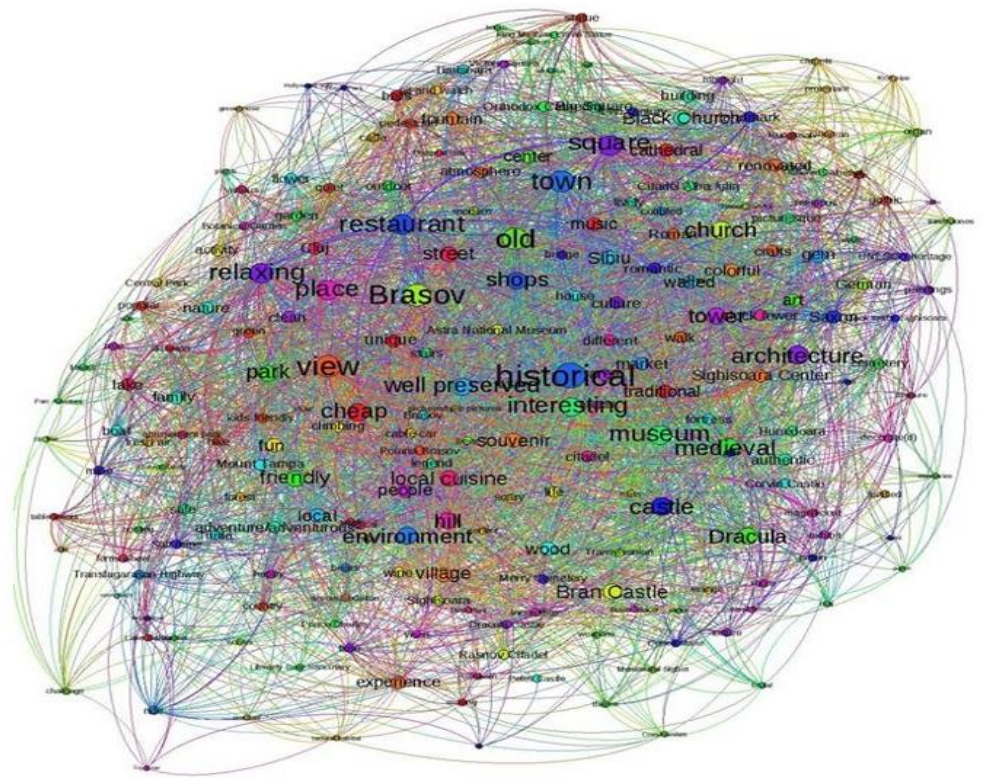

Figure 2: Text network showing the Degree Centrality Index 
Notions that do not only shape the themes coming about, but also establish connections among them have got an especially important role in the emerging network.

As it can also be seen on Figure 3, some keywords are present with not only a large number of nodes, but which are in contact with groups of nodes. These keywords, located in the centre of the network have got an outstanding importance due to their connecting nature. The following figure shows the text network based on the Betweenness Centrality Index, together with interlinked notion groups.

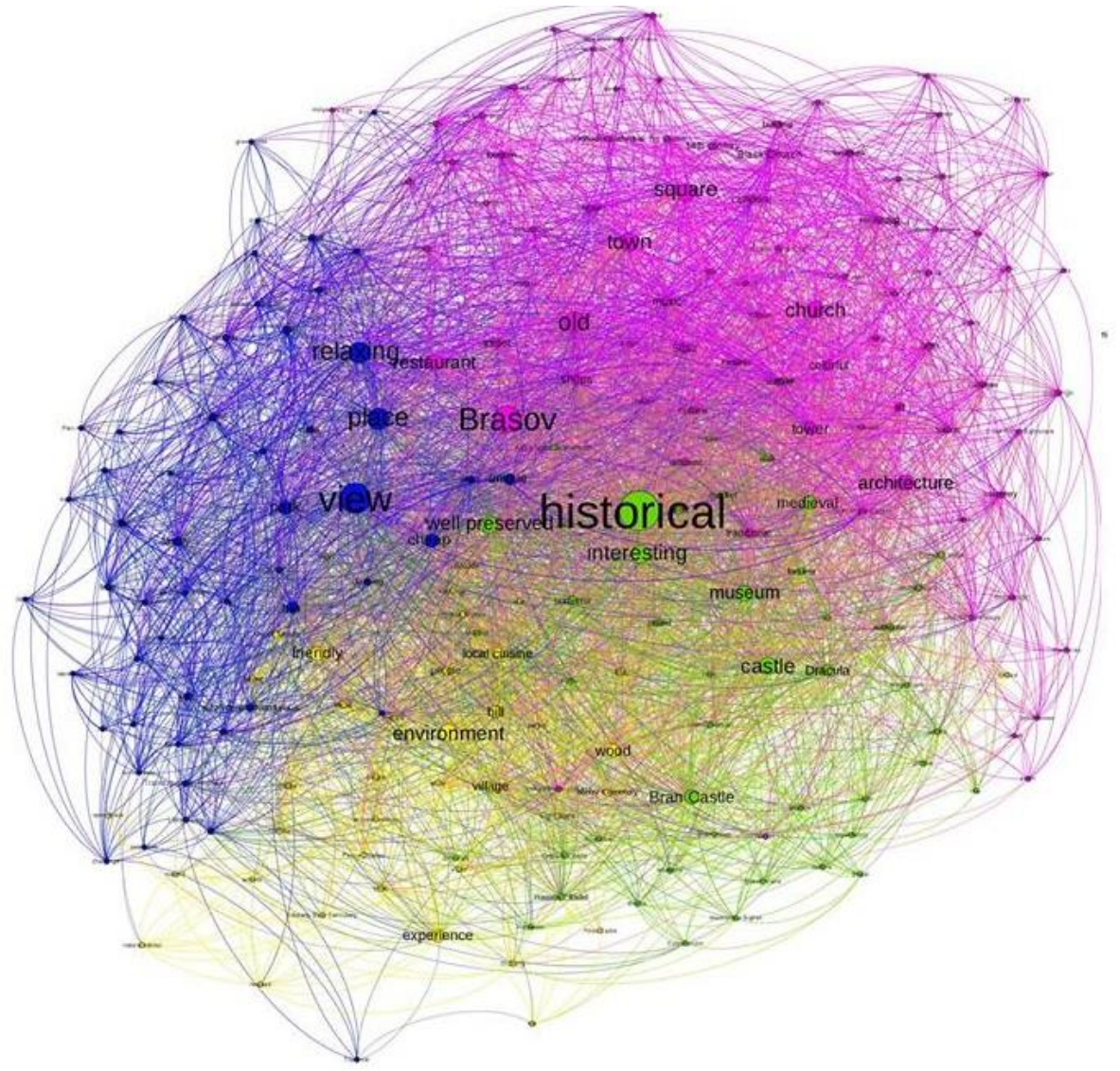

Figure 3: Text network showing Betweenness Centrality Index

The following table contains the first 20 notions and their indicators listed according to the betweenness centrality indicator.

Table 2: Values of the most important indicators from the perspective of the text

\begin{tabular}{|l|l|l|l|}
\hline Keyword & Degree & Closeness Centrality & Betweenness Centrality \\
\hline historical & 147 & 1.349557 & 1345.238580 \\
\hline view & 124 & 1.451327 & 987.438172 \\
\hline Brașov & 127 & 1.438053 & 834.357091 \\
\hline place & 107 & 1.530973 & 643.992569 \\
\hline \multicolumn{2}{c}{} \\
& $\mathbf{1 9 7}$ \\
\end{tabular}




\begin{tabular}{|l|l|l|l|}
\hline relaxing & 109 & 1.517699 & 629.004815 \\
\hline old & 122 & 1.460176 & 577.022261 \\
\hline interesting & 102 & 1.553097 & 512.373487 \\
\hline town & 117 & 1.482300 & 496.322823 \\
\hline square & 109 & 1.517699 & 481.389689 \\
\hline castle & 99 & 1.570796 & 474.465922 \\
\hline environment & 91 & 1.597345 & 471.917621 \\
\hline church & 96 & 1.579646 & 457.389102 \\
\hline well-preserved & 93 & 1.588495 & 454.327934 \\
\hline restaurant & 111 & 1.508849 & 406.834901 \\
\hline architecture & 98 & 1.570796 & 405.323873 \\
\hline museum & 104 & 1.539823 & 405.259877 \\
\hline Bran Castle & 81 & 1.641592 & 336.003286 \\
\hline park & 84 & 1.628318 & 326.630321 \\
\hline cheap & 95 & 1.592920 & 324.969843 \\
\hline friendly & 84 & 1.628318 & 322.607284 \\
\hline Source: & & \\
\hline
\end{tabular}

Source: based on our own calculation data

It can be seen both from the figures and the table that the words that shape themes also create linkages among them. The word with the biggest betweenness centrality index, 1345.238581 is 'historical', and this is also the keyword with the highest number of connections, a total of 147. The words 'view', and 'Brașov' appear second and third both by degrees and according to the betweenness centrality indicator. Based on this it can be said that these words do not only have the largest number of connections, but they also link together the different parts of the network, or in other words, these are the notions that hold the network together, making it more compact. Keywords like 'place', and 'relaxing' have fewer links, still they are important elements from the perspective of the complexity of the network. As we can also see on the following figure, these are key notions taking a central place in the emerging groups and along which the different topoi appear.

\section{Transylvanian Topoi}

Examining the clustering of the network it can be said that four different groups emerged within the text field, with a modularity value of 0.184 .

Figure 3: Network created based on the modularity indicator 


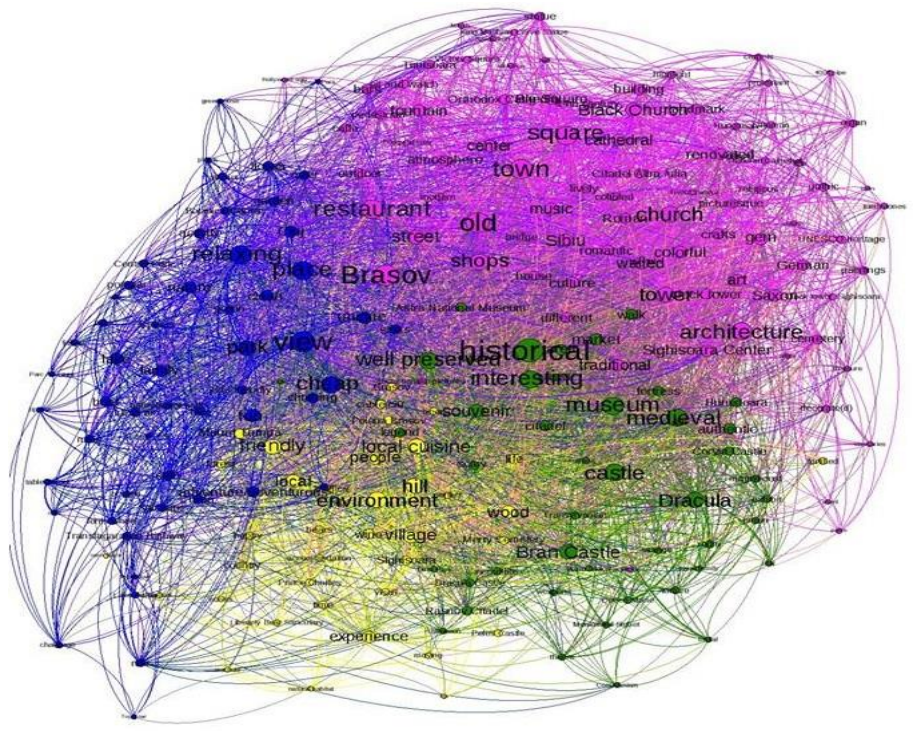

The thematic groups above are marked by different colours. The group marked by purple is the most extensive one, with $38.33 \%$ of the words linked to it. It was named "city experience". The second thematic groups is shown in green, it is also the second most significant one, including almost $23.79 \%$ of the words, consisting of notions related to "historical past". The third, blue coloured group is named "adventurous/ full of experience", and it includes almost $20.7 \%$ of the words, while the group marked with yellow, named "authentic/ close to nature", includes $17.18 \%$ of the notions.

The following table summarises the characteristics of the emerging four topoi in a synthetic form.

Table 3: Emerging topoi, key notions and themes discussed

\begin{tabular}{|c|c|c|c|c|c|}
\hline Topos & Ratio & Locations & Main Sights & Key Notions & Discussed Themes \\
\hline $\begin{array}{l}\text { "City } \\
\text { Experience" }\end{array}$ & $\begin{array}{l}\text { Purple } \\
38.33 \%\end{array}$ & $\begin{array}{l}\text { Sighișoara } \\
\text { Sibiu } \\
\text { Alba lulia } \\
\text { Brașov } \\
\text { Sighișoara } \\
\text { Timișoara } \\
\text { Cluj-Napoca }\end{array}$ & $\begin{array}{l}\text { Main squares } \\
\text { Sighișoara clock } \\
\text { tower } \\
\text { Black Church } \\
\text { Lutheran Cathedral } \\
\text { and clock tower } \\
\text { (Sibiu) } \\
\text { Orthodox Cathedral } \\
\text { (Timișoara) }\end{array}$ & $\begin{array}{l}\text { old (127), town (117), } \\
\text { restaurant (111), square } \\
(109) \text {, architecture (98), } \\
\text { church (96), shops (90), } \\
\text { tower (89), street (87), } \\
\text { Saxon (63), art (62), centre } \\
\text { (62), music (61) traditional } \\
\text { (61), colourful (60), } \\
\text { fountain (59) }\end{array}$ & $\begin{array}{l}\text { Saxon towns } \\
\text { Typical town } \\
\text { squares/centres } \\
\text { (post-modern character) } \\
\text { Iconic buildings as } \\
\text { meeting places } \\
\text { Animated, lively squares }\end{array}$ \\
\hline $\begin{array}{l}\text { "Historic } \\
\text { Past" }\end{array}$ & $\begin{array}{l}\text { Green } \\
23.79 \%\end{array}$ & $\begin{array}{l}\text { Hunedoara } \\
\text { Sibiu } \\
\text { Râșnov } \\
\text { Sighetul } \\
\text { Marmației }\end{array}$ & $\begin{array}{l}\text { Castle of Hunedoara } \\
\text { ASTRA National } \\
\text { Museum } \\
\text { Râșnov Citadel } \\
\text { Bran (Dracula) } \\
\text { Castle } \\
\text { Communist } \\
\text { Memorial in Sighetul } \\
\text { Marmației }\end{array}$ & $\begin{array}{l}\text { historical (147), museum } \\
\text { (104), interesting (102), } \\
\text { Mediaeval (101), castles } \\
\text { (99), Dracula (87), } \\
\text { souvenir (70), citadel (50), } \\
\text { fort (45), frightening (38), } \\
\text { Transylvania (30) }\end{array}$ & $\begin{array}{l}\text { Fairytale, mediaeval } \\
\text { castles (commodification, } \\
\text { Disney-isation) } \\
\text { Dracula story - the impact } \\
\text { of mass culture } \\
\text { Dark present age - } \\
\text { Communism }\end{array}$ \\
\hline
\end{tabular}




\begin{tabular}{|c|c|c|c|c|c|}
\hline $\begin{array}{l}\text { "Adventurous/ } \\
\text { Full of } \\
\text { Experience" }\end{array}$ & $\begin{array}{l}\text { Blue } \\
20.7 \%\end{array}$ & $\begin{array}{l}\text { Făgăraș } \\
\text { Mountains } \\
\text { Turda } \\
\text { Cluj-Napoca } \\
\text { Brașov } \\
\text { Timișoara }\end{array}$ & $\begin{array}{l}\text { Transfăgărășan } \\
\text { Route } \\
\text { Turda Salt Mine } \\
\text { Turda Gorge } \\
\text { Cluj-Napoca - } \\
\text { Central Park and } \\
\text { Botanic Gardens } \\
\text { Adventure Park in } \\
\text { Brașov } \\
\text { Timișoara - Park of } \\
\text { Roses }\end{array}$ & $\begin{array}{l}\text { view (124), relaxed (109), } \\
\text { place (107), cheap (95), } \\
\text { park (84), } \\
\text { individual (61), fun (68), } \\
\text { family (56), nature (56), } \\
\text { pure (52), adventure (51), } \\
\text { activity (46), climbing (46), } \\
\text { safe (41), child friendly } \\
(37)\end{array}$ & $\begin{array}{l}\text { Earning new experiences } \\
\text { Sights - Sports } \\
\text { relationship } \\
\text { (Adrenaline-rich } \\
\text { environment) } \\
\text { Tranquillity, relaxation }\end{array}$ \\
\hline $\begin{array}{l}\text { "Authentic } \\
\text { IClose to } \\
\text { Nature" }\end{array}$ & $\begin{array}{l}\text { Yellow } \\
17.18 \%\end{array}$ & $\begin{array}{l}\text { Brașov } \\
\text { Săpânța } \\
\text { Viscri }\end{array}$ & $\begin{array}{l}\text { Tâmpa - Mountain } \\
\text { Poiana Brașov } \\
\text { Merry Cemetery }\end{array}$ & $\begin{array}{l}\text { environment (91), hills } \\
\text { (85), friendly (84), local } \\
\text { cuisine (82), } \\
\text { countryside (70), people } \\
\text { (66), life (46), local wine } \\
\text { (46), forest (38), } \\
\text { time (33), magic (28), } \\
\text { accommodation (26), mill } \\
\text { (23) }\end{array}$ & $\begin{array}{l}\text { Rural life } \\
\text { Prince Charles effect } \\
\text { Ambivalent feelings in } \\
\text { connection with the Merry } \\
\text { Cemetery, Authenticity } \\
\text { Beauty of nature - hiking }\end{array}$ \\
\hline
\end{tabular}

Subsequently we will present the emerging topoi taking into consideration how the notions that shape them are connected to each other, and how the earlier mentioned places are filled and with what types of contents.

\section{City Experience}

As it can be deduced from its name, this topos depicts an urban Transylvania. The places alongside which the discourses are generated are the main squares of towns and cities, the centres of towns and the famous buildings that can be found here. The towns around which this text field is organised: Brașov, Sighișoara, Sibiu, Alba lulia, Timișoara as well as ClujNapoca. The most important key notions of this group - the ones with the highest number of connections, - describe the town feeling: old (122), town (117), restaurant (111), town square (109), architecture (98), church (90), tower (89), street (77), Saxon (63), art (62), centre (62), music and traditional (61), colourful (60), fountain (59).

"We loved Sighișoara, the historical centre was really awesome to visit. The houses look so cute, the atmosphere is great, there are a lot of restaurants, pubs, and people who are selling some awesome handmade souvenirs, from traditional masks and mediaeval outfits to accessories and decorations." (Woman, USA)

The main element of the topos is the urban square, with its restaurants, bars, souvenir shops and buildings. This square has got a post-modern character; it has become the scene of consumption, by the services that are provided there (Urry, 1995). Restaurants, outside terraces urge tourists to stay, and by that, to consume. Squares become the scene of illusion, and this is shown by the various markets and activities organised there (Árva, 2012, Urry, 1991).

"We spent hours walking around here (Brașov, Council Square). In the late afternoon there were sports activities for free, Rumba to disco music. This was very popular with many people. Not far from here is the lovely walk by the outer city walls, next to a pretty stream. Of course there is plenty of food and coffee available in the square, as well as shops of all sorts. Old Europe atmosphere." (Woman, Israel)

Squares show a similar outfit everywhere: narrow streets of cobblestone, surrounded by old, colourful buildings, fountains, flowers, restaurants, terraces, bars and iconic buildings in the proximity of the square - a church or a tower. The atmosphere is usually heightened by live music or concerts, occasionally activities, but as it turns out from the accounts of tourists, in most cases they just sit on benches and watch as people go by:

\section{“(...) great place for people watching” (Man, United Kingdom)}

“(...) Very entertaining to sit here and watch people come and go (Man) 
In general it can be said that this urban topos includes the largest cities and towns of Transylvania, respectively their main squares and centres. As it can be seen from the examples, the post-modern urban landscape is multi-coloured and diverse, including elements as: old-fashioned squares, we talk of designed beauty in such cases, textified facades, showing a rich view, style that emanate richness, wilful historical and geographic sights, and promenades, representing a breach between cars and pedestrian streets (Pásztor, 2006). This urban space can be described by three characteristics: mellowed by age, archaic, furthermore, they are the theatres of remembrance, and finally, one can say that they have become the scenes of spectacle and consumption. These buildings can be linked to the past, facilitate remembering; permit the visitor to peep in to discover the bygone centre, the old downtown. Finally the centre described by the tourists is colourful, full of life, thanks to organised activities, market fairs, live music and concerts. It is the show that entices tourists, and the services offered make them stay and consume.

\section{Historic Past}

This topos lays emphasis on the historic monuments of Transylvania. Places appearing here are mostly museums, castles, monuments. Towns where this discourse appears: Sibiu, Hunedoara, Râșnov, and Sighetul Marmației, while the main sights are the Bran (Dracula) Castle, The ASTRA National Museum Centre in Sibiu, the Corvin Castle of Hunedoara, and the Communist Memorial in Sighetul Marmației. The keywords with most connections that shape this topic are the following: historical (147), museum (104), interesting (102), mediaeval (101), castle (99), Dracula (87), souvenir (70), citadel (50), fortress (45), frightening (38), Transylvanian (30). From the comments it is quite clear that the tourists arriving here are very receptive with regard to perceived history and culture. A good example for that is the following remark:

ASTRA National Museum: "(...) 54 Hectares of Transylvanian culture all collected and beautifully presented. You will easily need 3 to 4 hours to take in this breathtaking collection of historic houses and buildings." (Woman, United Kingdom)

The effects of Disneyisation appears (Bryman, 2004), predominantly by virtue of the sights, as castles are endowed by fairy tale features: original furniture, narrow corridors, staircases, mediaeval arms, armours, all of which emphasise the fairy tale character of the scenes, travelling back to the past with the help of reconstructed objects, furnishings.

"The Corvin Castle in Hunedoara is a castle like in a fairy tale. From a distance you will already admit that this is an extraordinary beautiful castle to visit. Information about the rooms and history is plenty." (Man, Netherlands)

"(...) the architecture is very interesting. I've been there with children and they enjoy climbing up the stairs and going like in the labyrinth in the castle" (Woman, Ukraine)

Mediaeval fairs are frequent at these locations, just like souvenir shops, and thematic parks with various programmes, like the Dino Park at the Citadel of Râșnov, for instance. The effects of Disneyisation can best be felt here through thematisation, as one of the basic principles of the process is exactly this: historical scenes become thematic scenes. (Bryman, 2004)

\section{"(...) A couple of activities inside, like axe or spear throwing are available. Outside there's a small archery pit." (Man)}

The effects of mass culture can be mentioned as the strongest examples of commodification, especially in connection with the Dracula story. The most important features of popular culture are recreation and entertainment, which unfold in this case within the "vampire" theme. Many learn about the story from Bram Stoker's book and visit here to connect Vlad Țepeș with the vampire story found in the novel. Still, the information gathered during their visit helps them a lot in understanding history, and the accounts of the tourists relate that the castle is not only important from the perspective of the Dracula story, but they can also get an insight into the life of the royal family that had lived in Bran Castle.

History does not only appear by the mediaeval castles that fit into fairy tales, but also in connection with the communist memorial in Sighetul Marmației, where a tribute is paid to those persecuted by the communist regime. This place is no fairy tale scene; on the contrary, it permits a glance into darker times, as a former prison has been transformed into a museum: the cells, the torture rooms faithfully evoke the reality of that time. 
"It showed people could be ruthless in many ways just to maintain power! Torture room, picture of people who perished there. Solemn and unforgettable." (Man, Canada)

As a whole it can be said that the historical character of Transylvania can be grasped in different ways: starting with mediaeval fairy tale castles, through Dracula, and ending with the darker side of present times. In all three cases the importance of remembrance appears, the way the past is reconstructed, permitting to take a peep inside the world of bygone eras: with the help of costumes, decoration, thematic fairs, parks. By the particular presentation of the past these places and sights become the scenes of entertainment and become consumable, commodified. The exercise of reconstructing history turned fortresses, castles, museums, monuments into products, the sets, thematic parks, and fairs appearing there ensure entertainment, urging tourists to consume.

\section{Adventurous/ Full of Experience}

This discourse is organised mainly along activities and experiences gathered by them. The most important places in this topos are tourist sites that involve the active participation of the visitors. These attract tourists that are looking for adventure, challenges and for whom variety and entertainment are the main consideration. Places along which the text field sets up are: Cluj-Napoca, and the Central Park and the Botanic Gardens within it, the Transfăgărășan route, Adventure Park in Brașov, the Salt Mine in Turda, the Turda Gorge and the Park of Roses in Timișoara. The theme is shaped by the following key notions: panorama (124), peaceful (109), place (107), cheap (95), park (84), fun (68), unique (61), family, and nature (56), clean (52), adventure (51), activity (46), climb (46), safe (41), children friendly (37). These are the key notions with the largest number of connections.

"This is an amazing journey, as you snake up the mountain, wonderful views all around, and the trip down is simply out of this world. (...)" (Man, United Kingdom)

These places are most frequently visited by families or active young people looking for fun. In the first case we are talking about families with children, and from what they relate one can understand that these places are very safe and children friendly, in spite of the fact that quite a few extreme sports branches can be tried out, which becomes interesting mainly for the second group. As it can be seen from the feedback of visitors, these young people are ready to test their limits, to try out new things, which is true both for the hiking tours in the Turda Gorge and the Adventure Park in Brașov.

Adventure Park - Brașov: "This is a perfect place for a day out if you are seeking some real fun and activity. There are 7 routes from which 3 are for kids as well so you can take your family to have a great day. The place is very safe." (Man, United Kingdom)

The uniqueness of the Salt Mine in Turda given by its natural endowments is linked to the opportunities offered. As it can be read in the accounts there is even a small "amusement park" within the mine, appearing as one of the main scenes of entertainment:

"This place is huge. However, once on the ground floor, people were playing table tennis, bowling in the couple of bowling lane there, rowing in boats, we even rode a small ferris wheel to get closer to the stalactites. It was highly enjoyable with happy laughter (...)" (Woman)

Cluj-Napoca as a city can also be included into this topos: the Central Park and the Botanic Gardens provide numerous opportunities for tourists. It turns out that in addition to the activities, peacefulness appears here, the beauty of the park and of the garden, which are presented as a smaller oasis in the town. The bustling city appears in contrast to those.

\section{"It is an oasis for those who want calm moments in nature and yet close to the City centre" (Woman, Serbia)}

According to this topos Transylvania has got numerous adventurous opportunities: mountaineering, hiking, adventure parks. The adrenaline-full environment is also completed by nature as the scene of tranquillity. 


\section{Authentic/ Close to Nature}

This topos, as its name shows, is connected to the countryside of Transylvania, focusing on rural tourism. The topos is formed on the one hand along the areas visited by Prince Charles, and on the other hand along natural scenic spots. The scenic spots, respectively the localities within this discourse are the following: the Tâmpa Mountain, the Poiana of Brașov, Viscri, and the Merry Cemetery of Săpânța. The keywords that form the text field, and which have the largest number of connections are: environment (91), hills (85), friendly (84), local cuisine (82), countryside (70), people (66), life and local wine (46), forest (38), time (33), magic (28), accommodation (260), mill (23).

Tourists mostly link to rural life local food and drinks, traditional rural way of living, occupations, authentic accommodation, and friendly people, hospitality.

"We met people in the village- the local blacksmith, the brick maker and we helped in the fields. (...)The food was pure authentic local fare." (Man, United Kingdom)

It turns out from the discourse that there are villages mentioned by the tourists in connection with Prince Charles. As they said, the inspiration for their trip was the interest for Transylvania of the Prince of Wales

"Very nice to visit the villages were his majesty Prince of Wales, Charles found a refuge! (...)." (Woman, United Kingdom)

The Merry Cemetery as a site also involves a rural character/ village life, by the inscriptions on the graves present there, which introduce rural life and the customs of the people that had lived there. The Cemetery became widely known as it is part of World Heritage, and it rouses ambivalent feelings in visitors, sorrowful and simultaneously humorous by its illustrations and the poems written on the tombs.

"This is one of the most interesting cemeteries I have ever visited. The colourful memorials with their pictures of the life of the deceased person are both fun and moving" (Woman, United Kingdom)

\section{"(...) You will have a microcosm of village life over the last 85 years" (Man, Australia)}

As members of modern society tourists wish to experience authenticity, which unfolds in simplicity, poverty and virtuousness (Sharpley, 1999). Authenticity appears in two ways in relation with tourism: on the one hand in the form of the local products, food, costumes and buildings that constitute the culture of the community, and on the other hand as being distinct from mass tourism (Sharpley, 1999).

In general it can be said that Transylvania has got a rural, authentic character. The presence, the trips of Prince Charles greatly contributed to the development of local tourism. In connection with this discourse foreign tourists emphasise the kindness and the hospitality of the local people. The fact that they can get an insight into village life, observe how people live here, their occupations, represents some kind of escape for them from the noise of the town. Authentic accommodation, local cuisine and local wines all add a special flavour to this feeling. Rural life also appears from another perspective in connection with the Merry Cemetery, where the pictures drawn and the verses carved on the colourful gravestones allow an insight into the lives of local people.

This region is therefore authentic, with the people living here, their traditions, the untouched nature chosen by the tourists to experience stillness, and which provides relaxation in contrast with whirling city life.

\section{Summary}

As a whole it can be said that the representations produced by the tourists show a complex image of Transylvania, urban in one respect, with significant historical traditions, and yet at the same time close to nature, simultaneously offering the chance for active relaxation and tranquil astonishment. Its authenticity primarily appears in connection with the countryside, the way of living, the gastronomy, and the culture of its inhabitants. It can therefore be seen that this image differs from 
what earlier researches had shown in the case of tourists arriving from Hungary, which observed Transylvania as an exclusively rural, exotic, often underdeveloped region close to nature, where tourists flee to escape from noisy cities (Feischmidt, 2005, Sebestyén, 2005). By the commodification of the places of interest, the post-modern interpretation of the thematic activities, fairs, events, parks, squares Transylvania has become a colourful, globally marketable place.

\section{Reference List}

[1] Árva, László (2012). Új típusú turizmus, új típusú marketing a poszt-indusztriális korban. Szolnok: Szolnoki Főiskola.

[2] Bryman, Alan (2004). The Disneyization of Society. Sociological Review, 47, 125 26, $29-30$.

[3] Feischmidt, Margit (2005). A magyar nacionalizmus autenticitás diskurzusainak szimbolikus térfoglalása Erdélyben. In. Feischmidt, Margit (ed.): Erdély-(de)konstrukciók. Budapest: Néprajzi Múzeum - PTE Kommunikációs- és Médiatudományi Tanszék.

[4] Hanneman, Robert - Riddle, Mark (2005) Introduction to social network methods http://faculty.ucr.edu/ hanneman/nettext/C10 Centrality.html\#Intro (2016.09.15)

[5] Horváth, Alpár (2010): A területi turizmusfejlesztés lehetöségei Székelyföldön. Doktori értekezés. Pécsi Tudományegyetem Közgazdaságtudományi Kar Regionális Politika és Gazdaságtan Doktori Iskola.

[6] Jorgensen, Marienne \& Phillips Louise J. (2002). Discourse Analysis as Theory and Method. London: SAGE.

[7] Kiss, Tamás \& Barna Gergö \& Deák, Attila (2013). Székelyföldi turisztikai régió? Kérdőives, fókuszcsoportos és statisztikai vizsgálat a székelyföldi turizmusról. Cluj-Napoca: Nemzeti Kisebbségkutató Intézet.

[8] Nagy, Benedek (2015). Turizmus ami elválaszt és összeköt: a székelyföldi turisztikai kínálat továbbgondolási kísérlete. In Fábián Attila \& Bertalan Laura (eds.) Otthon a Kárpát-medencében: Területfejlesztési Szabadegyetem. Sopron: Nyugat-magyarországi Egyetem, p. 415-446.

[9] Pásztor, Gyöngyi (2006). Városszociológia. Elméletek es problémák. Cluj: Presa Universitară Clujeană.

[10] Pásztor, Gyöngyi \& Péter, László (2006). Kolozsvár mint márka - útban a posztmodern város felé? Szociológiai tanulmány egy erdélyi város jellegének és arculatának a változásáról. Erdélyi Társadalom 2006,2.

[11] Péter, László (2014). Football and Social Process. Issues and Problems in Soccer Discourses. Jyväskylä: University of Jyväskylä

[12] Popping, Roel (2000). Computer-assisted Text Analysis. London: SAGE

[13] Sebestyén, Adrienne (2005). „Erdélybe utazni más.” A magyar turisztikai irodalom Erdély-képe. In: Feischmidt Margit (szerk.): Erdély-(de)konstrukciók. Budapest: Néprajzi Múzeum - PTE Kommunikációs- és Médiatudományi Tanszék.

[14] Sharpley, Richard (1999). Tourism, Tourists and Society. Second Edition, Cambridgeshire: ELM Publications.

[15] Urry, John (1991). The Tourist Gaze. London: Sage.

[16] Urry, John (1995). Consuming Places. London: Routledge. 